\title{
$\mathrm{IF}$ 鋼 /ポリエチレン / IF 鋼積層板の力学特性評価
}

\author{
星野智顕* 井上博史 \\ 大阪府立大学大学院工学研究科マテリアル工学分野
}

J. Japan Inst. Met. Mater. Vol. 82, No. 4 (2018), pp. 85-88

(C) 2018 The Japan Institute of Metals and Materials

\section{Mechanical Characterization of IF Steel/Polyethylene/IF Steel Laminates}

Tomoaki Hoshino* and Hirofumi Inoue

Department of Materials Science, Graduate School of Engineering, Osaka Prefecture University, Osaka $599-8531$

In order to reduce the weight of metal materials with low cost, composites of metal and plastic were fabricated. IF steel with good formability was used for the metal. Polyethylene (PE) which has high strength and can be deformed later by thermoplasticity was used for the plastic. PE is a crystalline plastic and is well known to have a strong uniaxial orientation. Texture of such crystalline materials affects the mechanical properties. In this study, to clarify the relation between mechanical properties and texture in such composites, IF steel/polyethylene/IF steel laminates were fabricated by warm-rolling at two rolling reductions of $40 \%$ and $50 \%$, and strength of the laminates and textures of the constituent layers were investigated in detail. From pole figure measurements, when the rolling reduction is high, PE was oriented not only to the [001]//RD but also to the [100]//ND, resulting in biaxial orientation. Tensile strength of the IF steel layer was about 9 times higher than that of the PE layer, and that of the laminate was almost consistent with the calculated value by the rule of mixture. The IF steel layer with much higher strength showed isotropic tensile strength related to the $\gamma$-fiber texture of $<111>/ / \mathrm{ND}$, although the PE layer showed remarkable in-plane anisotropy resulting from the strong texture. As a result, tensile strength of the laminates was isotropic for both rolling reductions.

[doi:10.2320/jinstmet.JBW201706]

(Received November 2, 2017; Accepted December 19, 2017; Published February 2, 2018)

Keywords: IF steel, polyethylene, laminate, roll-bonding, mechanical properties

\section{1. 緒言}

近年, 地球温暖化や大気污染などの環境問題を抑制するた めに輸送機器の燃費向上が求められている. 航空機の機体に は超ジュラルミン, 超々ジュラルミンに代わって炭素繊維強 化プラスチック (CFRP)の使用が増加しており, 自動車産業に おいても一部のスポーツカーや高級車において CFRP が使用 され始めている. CFRP の密度は1.6程度であり, 輸送機器の 大幅な軽量化による燃費の向上が期待される. しかしながら, 製造コスト ${ }^{1)}$ やリサイクル ${ }^{2)}$, 材料の信頼性 ${ }^{3}$ 等の解決される ベき問題点も多い. 一方, 金属材料の信頼性は高く, プラス チックに比べて均一で安定した強度を有する．金属板とプラ スチック板の積層化により, 比強度を保持したまま制振性や 断熱性などの機能性を付加することができる. 所定の強度を 有する金属/プラスチック積層板は外板の軽量化が求められ ている自動車に利用できる可能性がある. 特にルーフへの使 用により, 雨音の軽減, 結露の防止効果が期待できる. しか しながら, 金属板とプラスチック板の積層化の研究は比較的 に少ない4-6). ポリエチレン (PE) は安価で高強度であるが無 極性高分子であるため, 金属との接合が難しく, 金属との積 層化によりどのような力学特性を示すか明らかではない.

本研究では, 構成物質の候補として金属に安価で成形性の

\footnotetext{
* 大阪府立大学大学院生 (Graduate student, Osaka Prefecture University)
}

良い $\mathrm{IF}$ 鋼, プラスチックに安価で高強度である $\mathrm{PE}$ を使用し た.また, PE は熱可塑性なので後の加工が可能であり, 成 形・材料の分離を容易にする. プラスチックの多くは非晶質 であるが, PEのような結晶性プラスチックでは, 一般的に結 晶化度が高くなると強度が増加する7). また, 結晶化領域は 塑性加工により配向性をもつことが多く ${ }^{8)}$, このような結晶 性材料は集合組織の発達が材料の力学特性に影響する。この ため, 複合材料を構成する物質の集合組織は複合材料の力学 特性と密接な関係があると考えられる，著者の一人は温間圧 延接合技術を用いて，チタンクラッドマグネシウム合金板の 作製に成功している ${ }^{9)}$. PE が圧延温度において融点を超え流 動状態になることで積層板の作製が可能と考え, 温間圧延接 合により IF 鋼／ポリエチレン／IF 鋼積層板を作製し, 強度 と集合組織の関係を調査した.

\section{2. 実 験 方 法}

本研究では深絞り性に優れている IF 鋼と熱可塑性樹脂のポ リエチレン $(\mathrm{PE})$ を積層板作製の素材とした，供試材の IF 鋼 は圧下率 $80 \%$ で冷間圧延した後に塩浴中 $1103 \sim 1113 \mathrm{~K}$ で $130 \sim 140 \mathrm{~s}$ 焼鈍した厚さ $0.25 \mathrm{~mm}$ の冷間焼鈍板である.これ は, 深絞り性に好都合な $\{111\}$ 面が圧延面に平行な集合組織 $\{111\}<\mathrm{uvw}>$ 方位 $(\gamma$-fiber $)$ を発達させるための圧延・焼鈍条件 である. PE は厚さ $1.00 \mathrm{~mm}$ の市販の板材である. IF 鋼板に ついては PE 板との接合面を圧延方向に金属ブラシで研磨し 
た、各試料ともに表面をエタノールで洗浄した.

IF 鋼 /ポリエチレン / IF 鋼積層板の作製は温間圧延によ り行った。 2 枚の IF 鋼板の間に PE 板を挟んで重ねた試料を $473 \mathrm{~K}$ に温めた炉にいれ10分間加熱した。 その後, 炉から取 り出し，素早く圧延機に通して無潤滑で圧延を行った。この ときの圧延速度は $5 \mathrm{~m} / \mathrm{min}$ であり，1 パスで圧下率は $40 \%$ と $50 \%$ のつの条件で 2 種類の試料を作製した。引張試験・X 線回折の試料作製には IF 鋼板 $(80 \mathrm{~mm} \times 50 \mathrm{~mm})$ と $\mathrm{PE}$ 板 $(80$ $\mathrm{mm} \times 50 \mathrm{~mm})$ を用い, 剥離試験には $\mathrm{IF}$ 鋼板 $(240 \mathrm{~mm} \times 50$ $\mathrm{mm})$ と $\mathrm{PE}$ 板 $(160 \mathrm{~mm} \times 50 \mathrm{~mm})$ を用いた。

これらの各試料に対して, 引張試験, $180^{\circ}$ 剥離試験による 力学特性評価, 光学顕微鏡観察による組織観察, $\mathrm{X}$ 線回折に よる集合組織測定を行った。 また，PEの結晶化度を求めるた めに嵩密度測定を行った。引張試験, $180^{\circ}$ 剥離試験は卓上形 精密万能試験機(島津製作所製 AGS-10kNX STD)を用いて 行った。引張試験はひずみ速度 $1 \times 10^{-3} \mathrm{~s}^{-1}$ で行った。圧下率 $40 \%$ と $50 \%$ の積層板 $(80 \mathrm{~mm} \times 50 \mathrm{~mm})$ それぞれから, 長手方 向が圧延方向 $(\mathrm{RD})$ に対して $0^{\circ}, 45^{\circ}, 90^{\circ}$ 方向の 3 方向になる ように $40 \mathrm{~mm} \times 15 \mathrm{~mm}$ の試験片を各 3 本切り出した。標点間 距離を $30 \mathrm{~mm}$ として, 引張試験を行った。また，圧下率40\% と $50 \%$ の積層板 $(80 \mathrm{~mm} \times 50 \mathrm{~mm})$ をそれぞれ剥離させて，IF 鋼と $\mathrm{PE}$ の単体も同様に引張試験を行った。 $180^{\circ}$ 剥離試験は JIS K6854-2を参考に剥離方向を RD, クロスヘッドスピード $0.833 \mathrm{~mm} / \mathrm{s}$, 試料幅 $20 \mathrm{~mm}$, 剥離長さ $125 \mathrm{~mm}$ で行った。積 層板の IF 鋼層を 1 枚剥がし, 試料の端部で PE 層を剥離させ, そこを起点として PE 層を必要分剥離させた，得られた曲線 は平滑化を行い，測定開始部付近と終了部付近を除く 8 点以 上のランダムな点を採取し, 最大值, 最小值, 平均值を求め た.こうして得られた值を試料幅で除することによって規格 化した．圧下率 $40 \%$ と $50 \%$ それぞれ 3 本の試料を測定し，そ れぞれの最大值，最小值，平均值の平均を算出した．積層板 断面を耐水エメリー紙で研磨し，光学顕微鏡観察を行った。 集合組織測定には圧延前の PE 板と圧下率 $40 \%$ ，50\%で作製 した積層板から取り出した 2 種類の $\mathrm{PE}$ 層を用いた。線源に は $\mathrm{CuK} \alpha$ 線 $(\mathrm{Ni}$ の $\mathrm{K} \beta$ フィルター使用)を使用した。 $\mathrm{PE}$ が斜 方晶 $(\mathrm{a}=0.741 \mathrm{~nm}, \mathrm{~b}=0.494 \mathrm{~nm}, \mathrm{c}=0.255 \mathrm{~nm})$ である ${ }^{10)}$ ので, (110) および $(200)$ について管電圧 $40 \mathrm{kV}$ ，管電流 $40 \mathrm{~mA}$ で Schulz の反射法 ${ }^{11)}\left(\alpha=30^{\circ} \sim 90^{\circ}\right)$ と透過法 ${ }^{12)}\left(\alpha=0^{\circ} \sim 30^{\circ}\right)$ で 完全極点図を測定した．それぞれ回折ピークの理論值は $2 \theta=$ $21.6^{\circ}, 2 \theta=24.1^{\circ}$ である. 反射法と透過法の接続は $\alpha=30^{\circ}$ で 行った．反射法用ランダム試料にはやすりで PEの板材を削 り作製した粉末を用いた。嵩密度はマイクロメーターと電子 天秤を用いて求めた. IF 鋼の測定には $\mathrm{MoK} \alpha$ 線 $(\mathrm{Zr}$ の $\mathrm{K} \beta$ フィ ルター使用)を使用し, 板厚中心部の RD-TD 断面で行った. IF 鋼は体心立方格子 (bcc)であるので，（110），(200），(211）, (310)について管電圧 $40 \mathrm{kV}$ ，管電流 $40 \mathrm{~mA}$ で Schulz の反射 法 $\left(\alpha=15^{\circ} \sim 90^{\circ}\right)$ で不完全極点図を測定した。 それぞれ回折 ピークの理論值は $2 \theta=20.1^{\circ}, 2 \theta=28.7^{\circ}, 2 \theta=35.4^{\circ}, 2 \theta=46.2^{\circ}$ である.ランダム試料は粉末 $\alpha-\mathrm{Fe}$ を用いた。 その後, 得ら れたデー夕に対して, 反復級数展開法による ODF 解析プロ グラム ${ }^{13)}$ (Standard ODF)を用いて方位分布関数を計算した。

\section{3. 結果と考察}

\section{1 光学顕微鏡観察と密度}

Fig. 1 に圧下率 $40 \%$ と $50 \%$ の積層板の断面写真を示す． IF 鋼層と PE 層が平行で接合界面に剥離がなく, 圧延により $\mathrm{PE}$ のみ厚さが変化していることがわかった。これは PEの融点

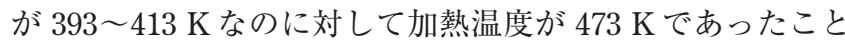
により，圧延接合時に非晶質の流動状態であったためである. Table 1 に各試料の嵩密度を示す。100\%結晶の PE の密度を $1.00 \mathrm{~g} / \mathrm{cm}^{3}, 100 \%$ 非結晶の PE の密度を $0.85 \mathrm{~g} / \mathrm{cm}^{3}$ として Table 1 の PE の嵪密度から PE の結晶度を求める ${ }^{14)}$ と $76 \%$ で あった．また，圧延前後で PEの高密度が変化していないこ とから PEの結晶度が圧延前後で変化していないことがわか る.

\section{2 力学特性評価}

Fig. 2 は圧下率 $40 \%$ と $50 \%$ で作製したそれぞれの積層板の
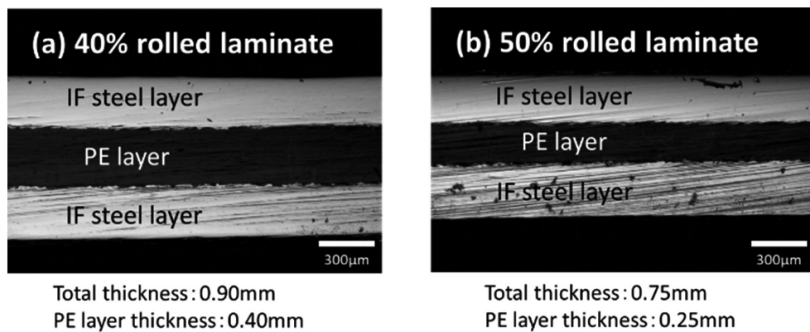

Fig. 1 Optical microstructures of laminates.

Table 1 Density of various materials.

\begin{tabular}{cc}
\hline Specimen & Density $\left(\mathrm{g} / \mathrm{cm}^{3}\right)$ \\
\hline As-received Fe & 7.81 \\
As-received PE & 0.96 \\
PE layer of $40 \%$ rolled laminate & 0.96 \\
PE layer of $50 \%$ rolled laminate & 0.96 \\
$40 \%$ rolled Fe/PE/Fe laminate & 4.77 \\
$50 \%$ rolled laminate & 5.53 \\
\hline
\end{tabular}

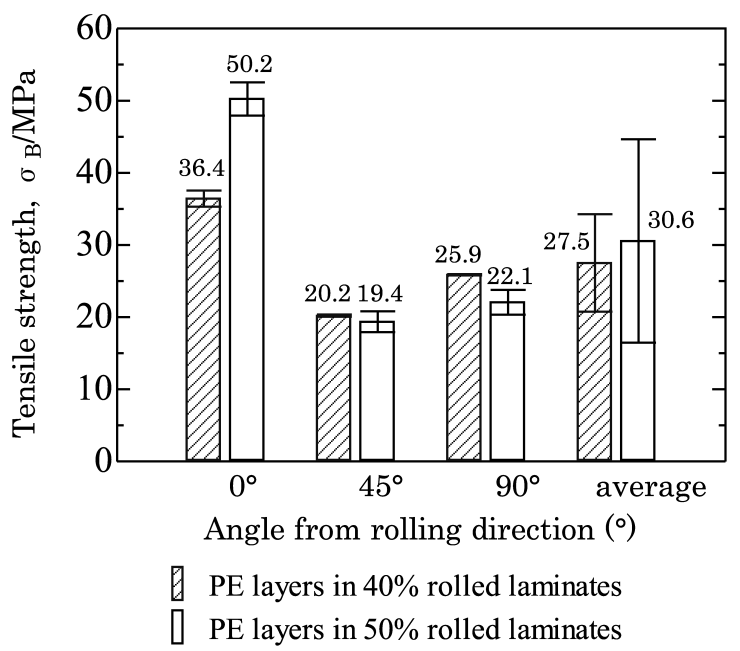

Fig. 2 Tensile strength in $0^{\circ}, 45^{\circ}, 90^{\circ}$ directions and their average of polyethylene layers in $40 \%$ and $50 \%$ rolled laminates, respectively. 
$\mathrm{PE}$ 層単体における引張強さを示す。どちらの圧下率でも $0^{\circ}$ 方 向の引張強さがほかの 2 方向に比べて高くなっていることが わかる.これは PE の高分子鎖が並んでいる方向が $c$ 軸であ $り^{15)}$ ，積層板作製時の温間圧延で PE の高分子鎖が RD 配向 になるためであると考えられる．圧下率が高い PE 層の方が $0^{\circ}$ 方向の引張強さが高く, $90^{\circ}$ 方向の引張強さが低いことよ り，圧下率が高いほど PE の高分子鎖が RD に配向し， RD 以 外の方向の高分子鎖の割合が減少するためであると考えられ る. また, Table 1 に示すように接合時の圧延前後で PE の嵪 密度に変化がないことから PE 全体の結晶度は変化せずに結 晶配向が変化していると考えられる.

Fig. 3 は圧下率 $40 \%$, Fig. 4 は圧下率50\%の積層板の実測の 引張強さと複合則によって算出した引張強さを示す．横軸の “average”は 3 つの角度の平均值を表わす。複合則の計算には IF 鋼層, $\mathrm{PE}$ 層それぞれ単体で引張試験した值を用いた，IF 鋼単体の引張強さはどの方向も $280 \mathrm{MPa}$ 程度であった。しか し, PE 単体の引張強さは Fig. 2 より, 異方性が認められるも のの $30 \mathrm{MPa}$ 程度であり, IF 鋼と比較してはるかに小さかっ た。積層板作製において IF 鋼板の厚さは変化しなかったた め, 積層板における IF 鋼と PE の体積分率を圧下率 $50 \%$ で $2 ： 1$, 圧下率 $40 \%$ で $5: 4$ とした. Fig. 3 より, PEの体積 分率が高い圧下率 $40 \%$ の積層板では $0^{\circ}$ 方向の実測の引張強さ

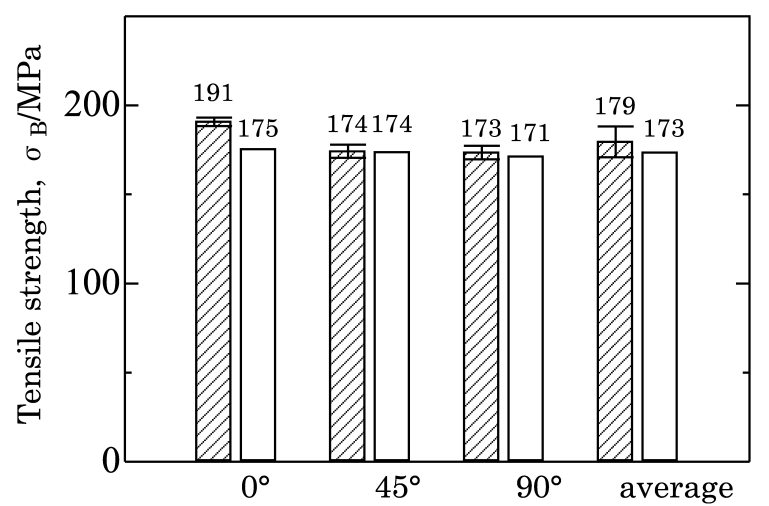

Angle from rolling direction $\left(^{\circ}\right)$

G Measured value [ Calculated value

Fig. 3 Measured and calculated tensile strengths of $40 \%$ rolled laminates. The calculation was made by the rule of mixture.

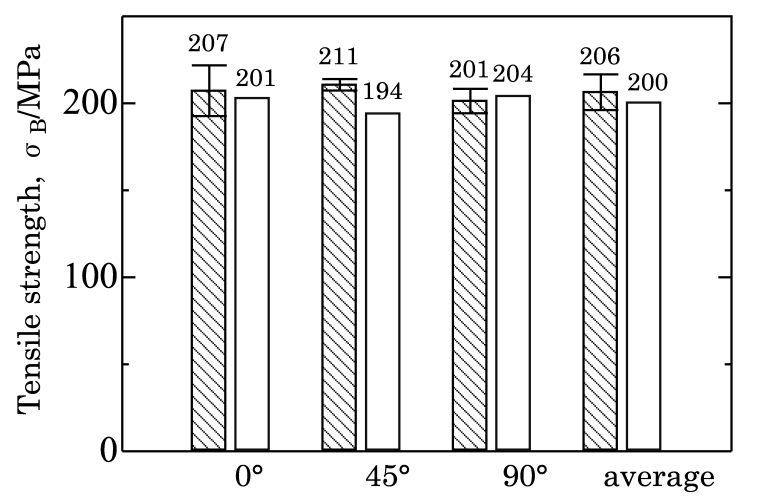

Angle from roling direction $\left(^{\circ}\right)$

\& Measured value [ Calculated value

Fig. 4 Measured and calculated tensile strengths of $50 \%$ rolled laminates. The calculation was made by the rule of mixture.
が他の 2 方向に比べて高くなっていることがわかった。これ は, 上述の $\mathrm{PE}$ 層における引張強さの面内異方性によるもの である. Fig. 4 より, PEの体積分率が低い圧下率50\%の積層 板では方向による引張強さの違いはみられなかった．圧下率 が高くなったことにより PE 層の引張強さにおける面内異方 性は大きくなっているにもかかわらず, 圧下率50\%の積層板 の引張強さが等方的であるのは PE の体積分率が低くなるこ とにより IF 鋼の引張強さの影響が大きくなったためである. 圧下率 $40 \%, 50 \%$ どちらの積層板でも実測の引張強さが複合 則で計算した引張強さとほぼ等しいことから, 積層板の引張 強さは複合則によって予測可能であると言える。

Table 2 に $180^{\circ}$ 剥離試験によって得られた各圧下率の平均・ 最大 ・ 最小剥離強度を示す. 平均 ・ 最大 ・ 最小剥離強度はど れも圧下率 $40 \%$ の方が高い值であった. 圧下率 $40 \%$ の積層板 の $\mathrm{PE}$ 層は圧下率 $50 \%$ の積層板の $\mathrm{PE}$ 層の約 1.6 倍の厚さがあ る. プラスチックを剥離層とする $180^{\circ}$ 剥離試験において剥離 層の曲げ変形の影響が剥離強度に加わる ${ }^{16)}$. 曲げ応力は材料 の厚さに依存するので, PE層の厚さの違いが剥離強度に影響 を与えたと考えられる。 どちらの圧下率でも剥離強度が低い ことから接合性を向上させる研究が必要である.

\subsection{IF 鋼と PE の集合組織変化}

圧下率 $40 \%$ 積層板の IF 鋼層の ODF を Fig. 5 に示す. IF 鋼

Table 2 Results of peeling tests.

\begin{tabular}{cccc}
\hline Specimen & $\begin{array}{c}\text { Average } \\
\text { peel strength } \\
(\mathrm{N} / \mathrm{mm})\end{array}$ & $\begin{array}{c}\text { Maximum } \\
\text { peel strength } \\
(\mathrm{N} / \mathrm{mm})\end{array}$ & $\begin{array}{c}\text { Minimum } \\
\text { peel strength } \\
(\mathrm{N} / \mathrm{mm})\end{array}$ \\
\hline $40 \%$ rolled & 0.091 & 0.125 & 0.063 \\
$50 \%$ rolled & 0.080 & 0.108 & 0.059 \\
\hline
\end{tabular}

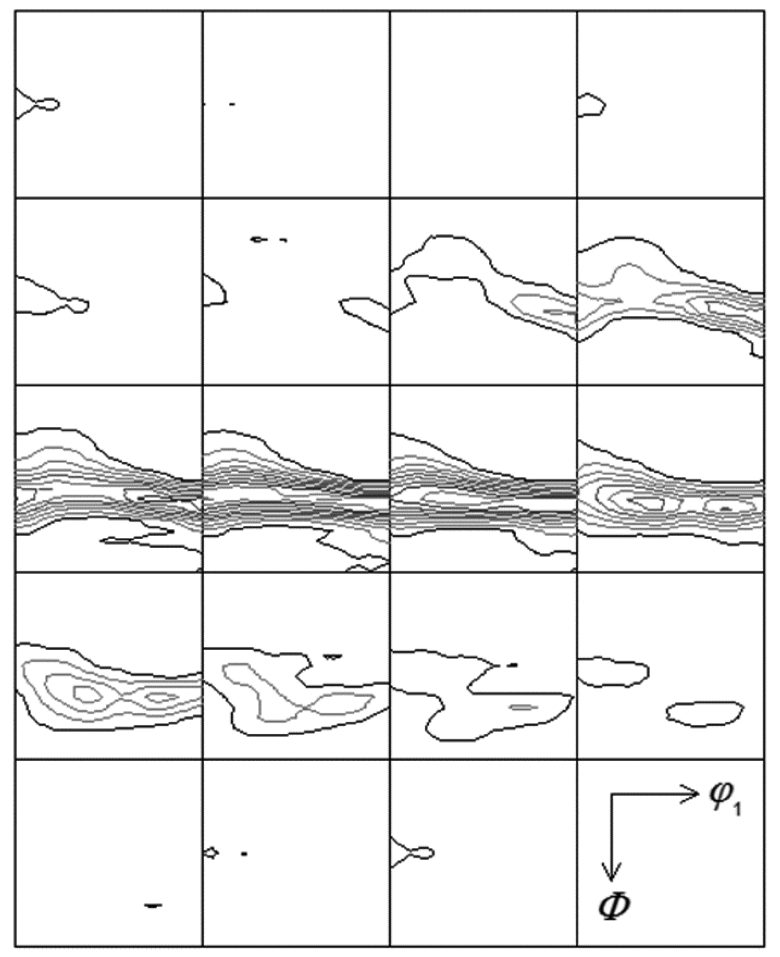

Contour Levels: $\begin{array}{llllllllll}1.0 & 2.0 & 3.0 & 4.0 & 5.0 & 6.0 & 7.0 & 8.0 & 9.0 & 10.0\end{array}$

Fig. 5 Orientation distribution function of IF steel layer in $40 \%$ rolled laminate. 


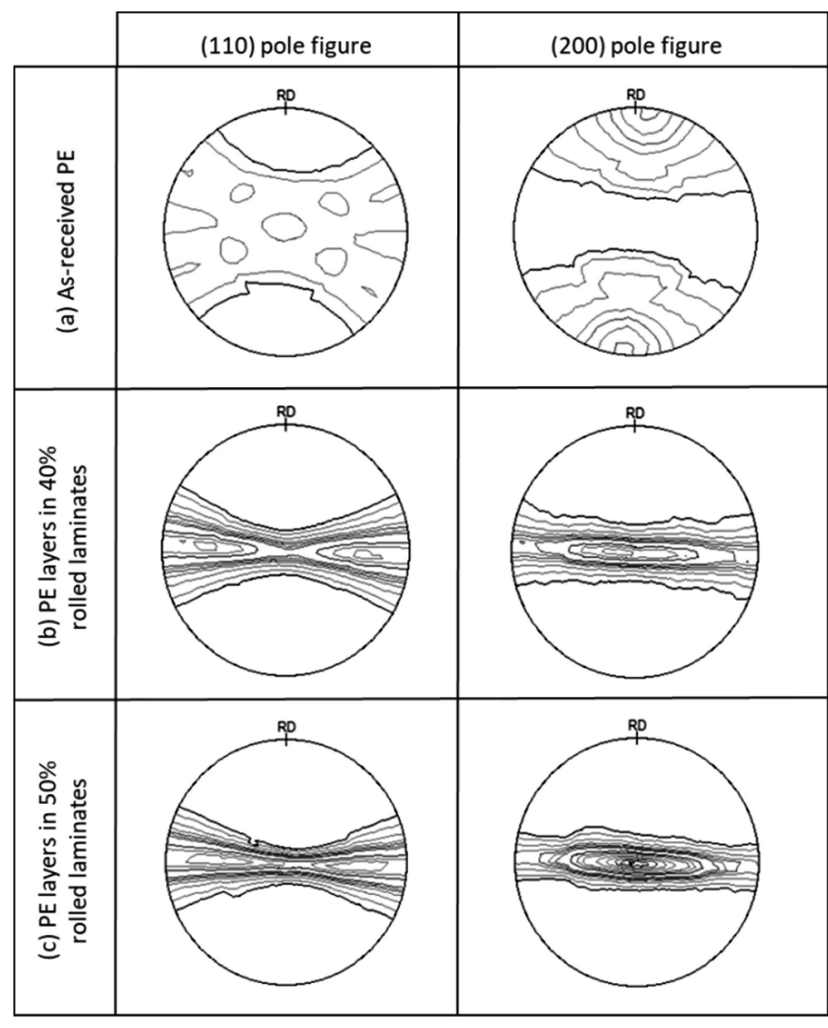

Contour Levels: $\begin{array}{lllllllllllllll}0.8 & 1.0 & 1.3 & 1.6 & 1.8 & 2.0 & 2.2 & 3.0 & 3.5 & 4.0 & 5.0 & 6.0 & 7.0 & 8.0 & 9.0\end{array}$

Fig. 6 (110) and (200) pole figures of (a) as-received polyethylene and polyethylene layers in (b) $40 \%$ rolled and (c) $50 \%$ rolled laminates.

の ODFをみると, 深絞り性の良好な $\{111\}<\mathrm{uvw}>$ 方位 $(\gamma \text {-fiber })^{17)}$ が強く表れていることがわかる，すなわち，IF 鋼の集合組織 は圧延前後でほとんど変化せずに $\gamma$-fiber を有することから, 圧延後も良好な深絞り性を保持することが推察される.

圧延前の PE 板と圧下率40\%,50\%積層板の PE 層の集合組 織変化を Fig. 6 に示す。圧下率 $40 \%$ 積層板中の PE 層と圧延 前の PE 板の (200) 極点図を比較すると, 圧下率 $40 \%$ 積層板中 の $\mathrm{PE}$ 層では $c$ 軸が $\mathrm{RD}$ と平行な結晶が多くなっていること がわかる，また，圧下率50\%積層板中の PE 層の (200) 極点図 では，圧下率 $40 \%$ で TD の方に広がっていた $a$ 軸の分布が極 点図の中心により集積していることがわかる。これは圧下率 $40 \%$ では $c$ 軸が RD に配向し， RD まわりに PE の結晶が回転 した状態で存在するが, 圧下率 $50 \%$ では $c$ 軸の $\mathrm{RD}$ 配向だけ でなく,$a$ 軸が圧延面法線方向 $(\mathrm{ND})$ に配向しつつあることを
示している. $\mathrm{PE} の c$ 軸配向は引張強さを高める ${ }^{18)}$ と考えられ るが，積層板では PEの強度がかなり低いために引張強さは IF 鋼の集合組織の影響により等方的である.

\section{4. 結言}

（1）積層板の引張強さは複合則による計算値とほぼ一致し た.

(2) 圧延により PE の結晶部分が配向し，PEの引張強さに 面内異方性が生じる。

(3) 圧下率が高くなると，PE は $c$ 軸が RD に配向するだけ でなく， $a$ 軸が NDに配向し，二軸配向となる。

(4) 接合時の圧延により PEの引張強さに面内異方性が生 じるが，面内異方性の小さい $\gamma$-fiber を持つ IF 鋼の引張強さ が PEよりもはるかに高いために積層板の引張強さはほぼ等 方的である.

文献

1) N. Shimizu: The Review of Laser Engineering 38(2010) 603-608.

2) T. Ueda, Y. Shimamura, K. Tohgo, T. Fujii, I. Okajima, M. Hiramatsu and T. Sako: J. Soc. Mater. Sci., Japan 59(2010) 964969.

3) S. Yashiro, J. Takatsubo, N. Toyama, T. Okabe and N. Takeda: J. Jpn. Soc. 72(2006) 1882-1887.

4) Y. Pan, G. Wu, Z. Huang, M. Li, S. Ji and Z. Zhang: Surface \& Coatings Technology 319(2017) 309-317.

5) N. G. Gonzalez-Canche, E. A. Flores-Johnson and J. G. Carrillo: Compos. Struct. 172(2017) 259-266.

6) S. Mousa and G. Y. Kim: Journal of Materials Processing Tech nology 239(2017) 133-139.

7) I. Nitta and H. Tadokoro: High Polymers, Japan 5(1956) 296301.

8) S. Hibi, K. Fujita, M. Maeda, T. Kakizawa, K. Imada and K. Takino: Sen-i Gakkaishi 36(1980) T371-T382.

9) H. Inoue: Titanium Japan 60(2012) 54-57.

10) W. R. Busing: Macromolecules 23(1990) 4608-4610

11) L. G. Schulz: J. Appl. Phys. 20(1949) 1030.

12) L. G. Schulz: J. Appl. Phys. 20(1949) 1033.

13) H. Inoue and N. Inakazu: J. Japan Inst. Met. Mater. 58(1994) 892-898.

14) W. Lin, M. Cossar, V. Dang and J. Teh: Polymer Testing 26(2007) 814-821.

15) L. Lin and A. S. Argon: J. Mater. Sci. 29(1994) 294-323.

16) J. Jang, M. Sung, S. Han and W. Yu: Compos. Struct. 160(2017) 118-127.

17) N. Sugiura, N. Yoshinaga, K. Kawasaki, Y. Yamaguchi and T. Yamada: Tetsu-to-Hagané 94 (2008) 179-187.

18) H. Kawai: High Polymers, Japan 10(1961) 308-315. 